\title{
Exploring the terrain of social entrepreneurship: new directions, paths less travelled
}

\section{Anne de Bruin and Simon Teasdale}

The field of social entrepreneurship (SE) is reaching maturity (Sassmannshausen and Volkmann 2018). However, there remain numerous new directions and paths less travelled for exploring the varied and complex SE terrain. This book draws together sixteen chapter contributions from developing paths of the SE field, to signpost directions ahead. In this chapter we integrate and build on these rich insights, paving the way for a future research agenda to advance the maturing SE field.

While some scholars suggest that mainstream entrepreneurship theories are sufficient to explain SE (Dacin et al. 2010), the field has been enriched by the application of different disciplinary approaches including management, public administration, economics, sociology, public health, and development studies. Up to this point methods have been predominately qualitative, arguably reflecting what a decade ago was characterised as a 'pre-paradigmatic' stage of field development (Nicholls 2010a), ranging from macro-studies of policy ecosystems to ethnographies. Economic theories have sought to explain the emergence of SE (Santos 2012) while realist evaluations (Roy et al. 2017) and systematic reviews (Calò et al. 2018; Roy et al. 2014) have been used to understand the impact of SE. Signs are emerging that scholars (and governments) are beginning to amass the datasets necessary for large-scale quantitative analysis (Estrin et al. 2013). While many authors use the terms social innovation, entrepreneurship and enterprise almost interchangeably, other scholars have focused on differentiating between them (de Bruin et al. 2014). Social innovation and SE are closely aligned. Despite this, the primary focus of this book is on SE, since a dual focus would have resulted in only thin coverage of both fields. However, the intricate and integral weaving together of the two fields is neatly captured in the final chapter of the book, Chapter 17 by Ziegler. The temporal perspective, future-orientation in capitalism and social imaginary ideas which are the crux of a chapter nominally focused on social innovation, are equally applicable to SE. As Ziegler aptly highlights, albeit in an endnote (note 1), his focus is on a strand of SE that relates to innovation and for brevity he refers to social innovations and social innovators, although this is not to assert that all social entrepreneurs are innovative. In similar vein, Luke and Chu (2013) show that not all social enterprises are entrepreneurial; although many chapters in this volume do not make such sharp distinctions between social enterprises and SE. 
We can trace the emergence of SE as a concept to early academic papers such as that by Waddock and Post (1991) who defined social entrepreneurs as "private sector citizens who play critical roles in bringing about catalytic changes in the public sector agenda and the perception of certain social issues" (p. 393). This definition reflects the attention paid to Schumpeter's hero entrepreneur extending out of economics and business management literature, and into domains of public administration and social policy. It also reflects the relabelling of the activities of US nonprofits within a frame that might appeal to donors at a time when capitalism had become the only game in town. Early work by pioneers of the academic field such as Dees (1998) maintained a focus on change agents in the social sector, and, similar to early work in the more mainstream field of entrepreneurship, began to trace out the traits of successful social entrepreneurs. A focus on exemplars of SE helped to establish people like Nobel laureate Muhammad Yunus as emblematic of SE (Choi and Majumdar 2014). But limiting SE to a 'rare breed' of heroic individuals (Dees 1998; Martin and Osberg 2007) effectively places boundaries around the concept which exclude potential beneficiaries from involvement in the solutions for the social problems they face (Eikenberry and Kluver 2004; see also Chapter 4 by Eikenberry). Yet, as researchers began focusing on SE as a process, the field of SE widened from a limiting focus on systemic change. Zahra et al. (2009) developed a typology of social entrepreneurs rooted in different theoretical traditions and distinguishable by the ways they act, the scale at which they operate, and their effects on the social equilibrium. This opened up the idea that the tools and concepts of SE research might be applied to a much wider variety of approaches, and from a variety of (macro- meso- and micro-) perspectives.

Therefore, our goal for this book was not only to showcase the range and depth of advances that currently characterise the SE field but also to move the field forward with re-thinking and blue-sky thinking on directions for covering new ground in exploring SE. Toward this end, we invited a range of scholars to contribute. They ranged from those who were already distinguished by their expertise on SE topics, some of whom also sought the opinions of their early career colleagues, to midcareer scholars with scholarly expertise on particular aspects and applications of SE. We also sought contributions from other established research areas that could draw out implications for SE - legal scholarship (Chapter 6), gender (Chapter 12), Indigenous research (Chapter 13) - as well as cover less traversed regional contexts (Chapters 14 and 15). Additionally, we attempted to bring in research contributions from emerging societal trends, for example the circular economy-ecological entrepreneurship-SE nexus (Chapter 11). Together this sets the scene for chapters that stretch imaginaries of both the futuristic and the everyday (see Chapters 16 and 17).

We abstain from providing an overview and summary of each of the chapters in the book. We leave it to the readers to glean first-hand the valuable insights these chapters offer. However, we do allude to the other chapters where relevant and generally we underscore and build on them in our discussion in this chapter of the less developed contours of the SE field and the scope they present for research. 


\section{Contours of the SE terrain}

In this section we take up some unresolved issues and gaps in the literature and point to directions for further exploration.

\section{Contestation}

It is notable that most usages of the concept of SE are positively imbued. To some extent, the enthusiastic portrayal of social entrepreneurs is a consequence of fieldbuilding exercises (Nicholls 2010a). In its early days the concept was treated more neutrally. For example, Breton and Breton (1969) conceptualise the social entrepreneur as the initiator of a social movement. Social movements grow around a shared conception of what possesses social value, and understandings of the causes of the problems they seek to tackle. However, whereas social movement scholars accept this contestation, within SE research there has been a tendency to avoid the 'dark side' (Williams and K'nife 2012). At heart, social value is a contested concept - what has value to one group may not necessarily be seen as having value by another. To illustrate, recent work (Chandra 2017) highlights the potential of SE to overcome terrorism through "disengag[ing] individuals enthralled to ideology and trapped by their own past behaviour" (p. 657). But from our privileged vantage point we should be mindful that the activities of Nelson Mandela and the African National Congress were once classified as terrorism by governments not only in South Africa, but also the United Kingdom. This of course is an extreme example, but we need to be alert to SE as modern form of colonialism which imposes a dominant set of values (Dey and Steyaert 2010). One route towards avoiding the contested nature of what has social value might be focusing on positively intended social change (Stephan et al. 2016). This reveals interesting paths less travelled for future research. Exploring $\mathrm{SE}$ as a site where contested ethics and values are played out between opposing factions offers much potential (Dey and Teasdale 2016). This in turn raises questions around the contested ethics and values of SE. Research from other fields may provide insights into methodological tools, such as Q methodology, designed to explore subjectivity and beliefs (Baker et al. 2006).

\section{Hybridity, competing logics}

Some authors switch interchangeably between SE and social enterprise, with the implication being that social entrepreneurs create and lead social enterprises. Others suggest SE extends well beyond social enterprises, perhaps because of the commercial constraints implied by social enterprise (e.g. Zahra et al. 2009). From this perspective, SE is not constrained to a single sector or subsector of the economy. The concept of hybridity perhaps offers a more useful lens through which to understand SE, since, as Chapter 15 by Holt and Meldrum illustrates, it is more adaptable to different cultural contexts.

The basic premise of hybridity is that social ventures bridge institutional fields (Tracey et al. 2011) by virtue of existing at the intersection between private, public 
and civil society, and so must accommodate the diverse logics, practices and values of these fields (Evers and Svetlik 1993). As such their bridging of institutional fields (Tracey et al. 2011) leads them to negotiate conflicting logics within the organisation, particularly around commercial and collective objectives (Doherty et al. 2014; Pache and Santos 2013). In the context of this book, SE involves conscious or unconscious strategies aimed at negotiating conflicting logics within the organisation (Doherty et al. 2014). These strategies more usually are aimed at alleviating tensions, selective coupling (or decoupling) (Pache and Santos 2013) or optimising conditions whereby social mission and commercial goals are in broad alignment (Battilana and Lee 2014).

While hybridity poses challenges to social entrepreneurs, it also offers opportunities to draw upon different organisational identities for different purposes. Drawing upon identity theory, Wry and York (2015) show how social entrepreneurs might be single minded (aligned either to a social or commercial logic), mixed (whereby role-based identity conflicts with personal identity), or balanced, whereby multiple role identities align with different logics. This begins to help explain how social ventures might normalise organisational complexity and hybridity. Nevertheless, it may also now be questioned whether social enterprises should continue to be classified as hybrid organisations (McMullen 2018). However, addressing questions of identity and reconciliation of tensions of multiple identities remain especially relevant, especially in the face of collaborative arrangements and partnerships including cross-sector interactions of social enterprises, nowadays an enduring ethic of SE (de Bruin et al. 2017).

\section{Rurality}

Extant studies have shown that SE can play an important role in rural development and catalysing solutions to socio-economic challenges in sparsely populated remote areas (Farmer et al. 2008; Steiner and Teasdale 2017; see also Chapter 10 by Eversole and Duniam). (Some) rural areas may have particular attributes (dense networks of trust and social capital) which lend themselves to SE (Lang and Fink 2018). Environmental sustainability, food insecurity in rural areas and vulnerability of smallholder farmers, agriurban and alternative food initiatives and food supply chain are all related issues that are being increasing tackled in the social economy and by social enterprises and offer fruitful areas for investigation (see Chapter 9 by Doherty and Kittipanya-ngam).

\section{Measuring social value}

While a constructivist perspective certainly poses challenges towards measuring social impact, academic literature on social impact measurement is wide and varied. Nicholls (2009) developed the construct of blended value accounting, showing how social entrepreneurs creatively use reporting practices as strategic tools to access resources. In many ways this is not dissimilar to the ways in which mainstream businesses present their annual accounts. But one notable difference 
is that in most countries, legislation determines which financial data should be reported, and to what standards. The quest to legitimise a single approach to social impact reporting brings to mind the battles fought between Betamax and VHS in the 1980 os as academics, practitioners, and accountancy firms seek to establish their own/chosen models as dominant practice (see also Chapter 5 by Ormiston and Castellas on the potential for practice insights for social impact measurement). Perhaps the most widely written-about method of social impact reporting is Social Return On Investment (SROI) (Arvidson et al. 2013), but it is widely accepted that SROI offers no realistic basis for comparing social performance of different types of social purpose organisation. Indeed, it is questionable whether such a basis for comparison is ever achievable, or even desirable, since it may push organisations to focus on what is measurable at the expense of experimentation and innovation (McMullen and Warnick 2016). While it may be feasible to ask organisations to collect data on immediate outputs, understanding longer-term impacts is expensive as well as subjective. Accordingly, there are good arguments that this should be left to funders (Ebrahim and Rangan 2014).

\section{Critical perspectives and governmentality}

Attempts by funders to measure social performance have been portrayed as embodying the high watermark of a new public management culture (Hall et al. 2012). The 'rational' thinking here was that if it were possible to place financial proxies on the activities and outputs of organisation, allocating resources would become a simple task easily aligned to political objectives. Perhaps recognising the futility of such command and control approaches, governments across the world, but particularly in market-liberal societies such as the UK, Australia and the US, have attempted to increase the supply of social ventures and manipulate their activity towards particular political objectives through more subtle 'governmentality' approaches such as discourse and the manipulation of material incentives. Discursive analysis of SE texts has sought to reveal how language functions in maintaining/changing power relations. Scholars (Dart 2004; Dey and Steyaert 2012; Dey and Teasdale 2016; Eikenberry and Kluver 2004; Ruebottom 2013) note that many of these texts (both academic and policy) highlight the role of the hero social entrepreneur as moving behind the constraints imposed by bureaucratic governments and wellmeaning but ultimately patronising and ineffective charities through the adoption of business-like approaches (see Dees 1998; Yunus 2011). Researchers adopting a discursive perspective have focused on resistance to dominant SE discourse from civil society practitioners (Parkinson and Howorth 2008), the implication being that since many practitioners 'reject' the dominant discourse, such attempts to manipulate behaviour have failed. However, the language of SE has become more prevalent than such resistance would predict (Dey and Teasdale 2013), and that resistance/compliance is not a simple dichotomy (Dey and Teasdale 2016). Other studies move the focus beyond discourse to focus on how policymakers manipulate behavioural levers through a blend of financial incentives (grants and contracts) and associated performance measurement techniques (Carmel and Harlock 2008). Hall et al. (2012) analysed the role of the UK's National Health Service in seeking 
to increase the supply of social enterprises operating in the health sector and encourage them into particular types of behaviour through the use of market-based incentives. Their conclusions lend further support to the notion that governments have not yet developed the tools to successfully manipulate the behaviour of social entrepreneurs. In Chapter 3, Mason picks up this line of questioning using a quasimarket illustration. Nonetheless, there remains a considerable gap in our knowledge concerning how governments and social entrepreneurs collaborate and/or come into conflict, and how this changes over time and context (see Chapters 2 and 4 by Roy and Hazenberg, and Eikenberry respectively).

\section{Field building and institutional environment/ecosystems}

The importance of contextual factors supporting, and constraining, SE is increasingly highlighted in the academic literature. There is a particular focus on the roles that government can play, through legislative instruments, in reshaping markets to financially reward the creation of social value (Ebrahim et al. 2014; Teasdale et al. 2012). Here studies have focused on legal forms for social ventures (Galera and Borzaga 2009; Nicholls 201ob; Reiser 2011), and tools such as social impact bonds aimed at bringing the financial efficiency of markets (Nicholls and Teasdale 2017) to the social sphere (Edmiston and Nicholls 2018; McHugh et al. 2013).

At the macro level this has been related to the development of SE as a field (Nicholls 2010a), and some studies have begun to focus on such field building through different institutional lenses: historical (Kerlin 2013; Roy et al. 2015; Sepulveda 2015; see also Chapter 2 by Roy and Hazenberg), and discursive (Nicholls and Teasdale 2017). Interestingly, as with much of the SE literature, when viewed from the macro level, scholars tend to derive a less positive analysis, particularly towards policy attempts to create a conducive environment for SE. In many countries, it would seem that the actions of policymakers are guided towards the replacement of (albeit) imperfect systems of social protection. Future research might usefully begin to unpack resistance to such social change activities (Dacin et al. 2011).

\section{Beyond the individual hero}

Early work tended to downplay or take for granted the social aspect of SE. Effectively 'social' was used in a residual sense to reflect social purpose organisations. Mair and Martí (2006) moved the focus away from the entrepreneur and began to focus on the ways in which social entrepreneurs are embedded in communities and draw upon resources within these communities. This helped switch attention towards the collective dimension of SE. Viewed through a collective lens, this demonstrates that all SE should be seen as a form of collective action, but also highlights particular approaches to SE that explicitly emphasise this collective dimension: social movements, community cooperatives, and cross-sectoral collaborations (Montgomery et al. 2012; see also Chapter 8 by Spear). Other authors focus on community enterprises as a particular form of social venture which bring to the fore the collective dimension within SE (see Chapter 7 by Haugh and Brady). 


\section{Towards intersectionality}

Interestingly, despite the attention paid within much of the discourse around SE as a means for tackling gender inequality, few studies explicitly explore SE as a gendered practice. Dempsey and Sanders (2010) show how SE can be conceived as the marketisation of reproductive labour and highlight the tensions this engenders. On the one hand, it makes such work 'meaningful', but on the other hand, through marketisation and professionalisation, SE might also serve to make meaningful work less accessible to women. To some extent this offers new insights into a quantitative literature which highlights that women may be overrepresented in the third sector and social enterprises, but the highest occupational levels are dominated by men (Teasdale et al. 2011). As such, work becomes professionalised and characterised by long hours and a 'macho' culture, and women are pushed (or pulled) away from positions of leadership.

A small number of studies have focused on efforts by social ventures to promote gender and development objectives. A study of a women's cooperative by Datta and Gailey (2012) suggests that collective entrepreneurship can empower women economically. However, work by Hayhurst (2014) indicates that when practised by international nongovernmental organisations, such SE efforts may actually further gender inequalities through focusing on short-term solutions (enabling women to cope in a 'man's world) while overlooking the broader structural inequalities and gender relations that marginalise women in the first place. In essence this is central to the critique of SE put forward by many scholars: that it can never achieve structural change through tackling the effects of inequality rather than the causes (Garrow and Hasenfeld 2014). This is a critique that has been levelled more widely at development practices in the Global South, so it is perhaps surprising that, as noted in Chapter 15 by Holt and Meldrum, there are relatively few studies of SE in the South; most existing studies focus on the efforts of Western-based NGOs and foundations (such as Ashoka) rather than on indigenous SE.

Thus, we draw attention to the need to extend the study of SE beyond the tried and tested Global North (see Chapters 14 and 15 by Alarifi, Robson and Kromidha, and Holt and Meldrum, respectively). Questions to be investigated include: What does SE mean for development, and developing and emerging economies? What does SE look like when interrogated through a postcolonial lens? How do we incorporate gender (see Chapter 12 by Lewis and Henry), and ethnicity and Indigenous perspectives (see Chapter 13 by Henry and Dana)? What is the role for SE in sustainable development? Perhaps most important, we would call for researchers to avoid focusing on particular inequalities in isolation; and begin to incorporate the concept of intersectionality in order to understand how different disadvantages combine and interact, and to explore whether hybrid organisations might possess particular advantages in overcoming multi-faceted social problems. Furthermore, intersectional research relies on bridging disciplinary boundaries and drawing on theories across disciplines. Given that diversity is a strength of the SE field, as discussed in the next section, this makes our call for intersectional analysis all the more apt. 


\section{Pluralism and multi-disciplinary advantage}

A strength of the SE field is its diversity in theoretical, disciplinary and methodological approaches, and as the field has matured, we have seen signs of considerable advancement in the interdisciplinary approach to studying SE. Arguably, this stems in part from the interdisciplinary conversations and cross-pollination of ideas stimulated through events such as the International Social Innovation Research Conference which will be in its eleventh year in 2019. The combination of different perspectives can help build exciting new theory. Disciplines where SE is perhaps still underrepresented include Development Studies, Sociology and Economics. Geography is another discipline that would seemingly lend itself to further study of SE as contextually and spatially determined.

It is not new to suggest that $\mathrm{SE}$ as a field is characterised by a lack of large-scale quantitative studies. Some would suggest this is partly a consequence of us not (yet) possessing a general theory of SE setting out its defining characteristics and general principles. Others from a more institutionalist slant would argue that such a general theory is impossible given the contextual interdependence between micro-social entrepreneurial initiatives and their politically, culturally, socially, economically, geographically, and historically variable contexts within which they operate. In essence, social ventures emerge to fit their context, making comparison impossible. Here the work led by Defourny and Nyssens as part of the ICSEM (International Comparative Models of Social Enterprise $)^{1}$ offers an exciting way forward. The ICSEM project seeks to identify and map broad families of social enterprise and relate their prevalence to institutional factors.

Much of the existing work on SE has relied on relatively light touch case studies to help build the field. As noted above, much of this work is relatively uncritical and can lead to an overly optimistic view of the field. Where researchers have undertaken more in-depth qualitative work challenges to this perspective emerge, such as around failure (Tracey and Jarvis 2006), and SE as performance (Mauksch 2016) involving deviance and mimicry (Dey and Teasdale 2016). A common thread running through these studies is the search by social entrepreneurs to carve out a path for agency within structuralist systems. Studying the creativity of social entrepreneurs and the ways in which they negotiate the spaces of power is one way in which the concept could permeate the sociological literature more deeply.

In measuring social impact, we can learn more from disciplines such as economics and development studies, more used to studying the effects of complex social interventions. Can we adopt 'gold standard' methodological approaches such as Randomised Control Trials to the study of SE? How can we ascertain the counterfactual? We need to be mindful here of the possibility for natural experiments. Realist evaluation offers one route forward in negotiating the problems of contextual interdependence, while, philosophically at least, offering potential to bridge the structure/agency divide. 


\section{Concluding comment}

Our overarching goal for the book was not to be prescriptive, but rather to stimulate the imagination in new ways. As an expedition to pave new ways to build cumulative knowledge in the maturing SE field, the book highlights future research directions that the complex dynamics and phenomena of SE offer. SE in its many and varied forms holds much promise for stimulating positive social change. This potentially includes systemic change through tackling deep-rooted global-level societal challenges such as poverty and environmental degradation; institutional change through tackling structural constraints such as improving women's empowerment in meaningful ways; and community change by tackling local-level social vulnerabilities such as inadequate housing for socio-economically disadvantaged groups. Now let the fascinating and rewarding exploration of the SE terrain pick up the pace, traversing not only gently undulating ground, but also land less trodden, rocky and steep.

NOTE

1 https://www.iap-socent.be/icsem-project.

\section{References}

Arvidson, M., F. Lyon, S. McKay and D. Moro (2013), 'Valuing the social? The nature and controversies of measuring Social Return on Investment (SROI)', Voluntary Sector Review, 4 (1), 3-18.

Baker, R., C. Thompson and R. Mannion (2006), 'Q methodology in health economics', Journal of Health Services Research E Policy, 11 (1), 38-45.

Battilana, J. and M. Lee (2014), 'Advancing research on hybrid organizing - insights from the study of social enterprises', The Academy of Management Annals, 8 (1), 397-441.

Breton, A. and R. Breton (1969), 'An economic theory of social movements', The American Economic Review, 59 (2), 198-205.

Calò, F., S. Teasdale, C. Donaldson, M. J. Roy and S. Baglioni (2018), 'Collaborator or competitor: assessing the evidence supporting the role of social enterprise in health and social care', Public Management Review, 20 (12), 1790-814.

Carmel, E. and J. Harlock (2008), 'Instituting the "Third Sector" as a governable terrain: partnership, procurement and performance in the UK', Policy \& Politics, 36 (2), 155-71.

Chandra, Y. (2017), 'Social entrepreneurship as emancipatory work', Journal of Business Venturing, 32 (6), 657-73.

Choi, N. and S. Majumdar (2014), 'Social entrepreneurship as an essentially contested concept: opening a new avenue for systematic future research', Journal of Business Venturing, 29 (3), 363-76.

Dacin, P. A., M. T. Dacin and M. Matear (2010), 'Social entrepreneurship: why we don't need a new theory and how we move forward from here', The Academy of Management Perspectives, 24 (3), 37-57.

Dacin, M. T., P. A. Dacin and P. Tracey (2011), 'Social entrepreneurship: a critique and future directions', Organization Science, 22 (5), 1203-13.

Dart, R. (2004), 'The legitimacy of social enterprise', Nonprofit Management and Leadership, 14 (4), $411-24$.

Datta, P. B. and R. Gailey (2012), 'Empowering women through social entrepreneurship: case study of a women's cooperative in India', Entrepreneurship Theory and Practice, 36 (3), 569-87. 
de Bruin, A., E. Shaw and D. Chalmers (2014), 'Social entrepreneurship: looking back, moving ahead', in E. Chell and M. Karatas-Ozkan (eds), Handbook of Research in Entrepreneurship and Small Business, Cheltenham: Edward Elgar Publishing, pp. 392-416.

de Bruin, A., E. Shaw and K. V. Lewis (2017), 'The collaborative dynamic in social entrepreneurship', Entrepreneurship \& Regional Development, 29 (7-8), 575-85.

Dees, J. G. (1998), The Meaning of Social Entrepreneurship, Duke University, Fuqua School of Business.

Dempsey, S. E. and M. L. Sanders (2010), 'Meaningful work? Nonprofit marketization and work/life imbalance in popular autobiographies of social entrepreneurship', Organization, 17 (4), 437-59.

Dey, P. and C. Steyaert (2010), 'The politics of narrating social entrepreneurship', Journal of Enterprising Communities, 4 (1), 85-108.

Dey, P. and C. Steyaert (2012), 'Social entrepreneurship: critique and the radical enactment of the social', Social Enterprise Journal, 8 (2), 90-107.

Dey, P. and S. Teasdale (2013), 'Social enterprise and dis/identification', Administrative Theory \& Praxis, 35 (2), 248-70.

Dey, P. and S. Teasdale (2016), 'The tactical mimicry of social enterprise strategies: acting "As If" in the everyday life of Third Sector organizations', Organization, 23 (4), 485-504.

Doherty, B., H. Haugh and F. Lyon (2014), 'Social enterprises as hybrid organizations: a review and research agenda', International Journal of Management Reviews, 16 (4), 417-36.

Ebrahim, A., J. Battilana and J. Mair (2014), 'The governance of social enterprises: mission drift and accountability challenges in hybrid organizations', Research in Organizational Behavior, 34, 81-100.

Ebrahim, A. and Rangan, V. K. (2014), 'What impact? A framework for measuring the scale and scope of social performance', California Management Review, 56 (3), 118-41.

Edmiston, D. and A. Nicholls (2018), 'Social impact bonds: the role of private capital in outcome-based commissioning', Journal of Social Policy, 47 (1), 57-76.

Eikenberry, A. M. and J. D. Kluver (2004), 'The marketization of the nonprofit sector: civil society at risk?', Public Administration Review, 64 (2), 132-40.

Estrin, S., T. Mickiewicz and U. Stephan (2013), 'Entrepreneurship, social capital, and institutions: social and commercial entrepreneurship across nations', Entrepreneurship Theory and Practice, 37 (3), 479-504.

Evers, A. and I. Svetlik (eds) (1993), Balancing Pluralism: New Welfare Mixes in Care for the Elderly, Aldershot: Avebury.

Farmer, J., A. Steinerowski and S. Jack (2008), 'Starting social enterprises in remote and rural Scotland: best or worst of circumstances?', International Journal of Entrepreneurship and Small Business, 6 (3), $450-64$.

Galera, G. and C. Borzaga (2009), 'Social enterprise: an international overview of its conceptual evolution and legal implementation', Social Enterprise Journal, 5 (3), 210-28.

Garrow, E. E. and Y. Hasenfeld (2014), 'Social enterprises as an embodiment of a Neoliberal welfare logic', American Behavioral Scientist, 58 (11), 1475-93.

Hall, K., P. Alcock and R. Millar (2012), 'Start up and sustainability: marketisation and the Social Enterprise Investment Fund in England', Journal of Social Policy, 41 (4), 733-49.

Hayhurst, L. M. C. (2014), 'The "Girl Effect” and martial arts: social entrepreneurship and sport, gender and development in Uganda', Gender, Place \& Culture, 21 (3), 297-315.

Kerlin, J. A. (2013), 'Defining social enterprise across different contexts: a conceptual framework based on institutional factors', Nonprofit and Voluntary Sector Quarterly, 42 (1), 84-108.

Lang, R. and M. Fink (2018), 'Rural social entrepreneurship: the role of social capital within and across institutional levels', Journal of Rural Studies, accessed 18 December 2018 at https://doi.org/10.1016/j. jrurstud.2018.03.012.

Luke, B. and V. Chu (2013), 'Social enterprise versus social entrepreneurship: an examination of the "why" and "how" in pursuing social change', International Small Business Journal, 31 (7), 764-84. 
Mair, J. and I. Martí (2006), 'Social entrepreneurship research: a source of explanation, prediction, and delight', Journal of World Business, 41 (1), 36-44.

Martin, R. L. and S. Osberg (2007), 'Social entrepreneurship: the case for definition', Stanford Social Innovation Review, Spring, 28-39.

Mauksch, S. (2016), 'Managing the dance of enchantment: an ethnography of social entrepreneurship events', Organization, 24 (2), 133-53.

McHugh, N., S. Sinclair, M. J. Roy, L. Huckfield and C. Donaldson (2013), 'Social impact bonds: a wolf in sheep's clothing?', Journal of Poverty and Social Justice, 21 (3), 247-57.

McMullen, J. S. (2018), 'Organizational hybrids as biological hybrids: insights for research on the relationship between social enterprise and the entrepreneurial ecosystem', Journal of Business Venturing, 33 (5), 575-90.

McMullen, J. S. and B. J. Warnick (2016), 'Should we require every new venture to be a hybrid organization?', Journal of Management Studies, 53 (4), 630-62.

Montgomery, A. W., P. A. Dacin and M. T. Dacin (2012), 'Collective social entrepreneurship: collaboratively shaping social good', Journal of Business Ethics, 111 (3), 375-88.

Nicholls, A. (2009), "We do good things, don't we?" "Blended Value Accounting" in social entrepreneurship', Accounting, Organizations and Society, 34 (6-7), 755-69.

Nicholls, A. (2010a), 'The legitimacy of social entrepreneurship: reflexive isomorphism in a pre-paradigmatic field', Entrepreneurship Theory and Practice, 34 (4), 611-33.

Nicholls, A. (2010b), 'Institutionalizing social entrepreneurship in regulatory space: reporting and disclosure by community interest companies', Accounting, Organizations and Society, 35 (4), 394-415.

Nicholls, A. and S. Teasdale (2017), 'Neoliberalism by stealth? Exploring continuity and change within the UK social enterprise policy paradigm', Policy \& Politics, 45 (3), 323-41.

Pache, A.-C. and F. Santos (2013), 'Inside the hybrid organization: selective coupling as a response to competing institutional logics', Academy of Management Journal, 56 (4), 972-1001.

Parkinson, C. and C. Howorth (2008), 'The language of social entrepreneurs', Entrepreneurship and Regional Development, 20 (3), 285-309.

Reiser, D. B. (2011), 'Benefit corporations - a sustainable form of organization?', Wake Forest Law Review, 46, 591-625.

Roy, M. J., R. Baker and S. Kerr (2017), 'Conceptualising the public health role of actors operating outside of formal health systems: the case of social enterprise', Social Science E Medicine, 172, 144-52.

Roy, M. J., C. Donaldson, R. Baker and S. Kerr (2014), 'The potential of social enterprise to enhance health and well-being: a model and systematic review', Social Science \& Medicine, 123, 182-93.

Roy, M. J., N. McHugh, L. Huckfield, A. Kay and C. Donaldson (2015), “'The most supportive environment in the world"? Tracing the development of an institutional "ecosystem" for social enterprise', Voluntas: International Journal of Voluntary and Nonprofit Organizations, 26 (3), 777-80o.

Ruebottom, T. (2013), 'The microstructures of rhetorical strategy in social entrepreneurship: building legitimacy through heroes and villains', Journal of Business Venturing, 28 (1), 98-116.

Santos, F. M. (2012), 'A positive theory of social entrepreneurship', Journal of Business Ethics, 111 (3), 335-51.

Sassmannshausen, S. P. and C. Volkmann (2018), 'The scientometrics of social entrepreneurship and its establishment as an academic field', Journal of Small Business Management, 56 (2), 251-73.

Sepulveda, L. (2015), 'Social enterprise - a new phenomenon in the field of economic and social welfare?', Social Policy \& Administration, 49 (7), 842-61.

Steiner, A. and S. Teasdale (2017), 'Unlocking the potential of rural social enterprise', Journal of Rural Studies, accessed 18 December 2018 at https://doi.org/10.1016/j.jrurstud.2017.12.021.

Stephan, U., M. Patterson, C. Kelly and J. Mair (2016), 'Organizations driving positive social change: a review and an integrative framework of change processes', Journal of Management, 42 (5), 1250-81.

Teasdale, S., P. Alcock and G. Smith (2012), 'Legislating for the Big Society? The case of the Public Services (Social Value) Bill', Public Money \& Management, 32 (3), 201-8. 
Teasdale, S., S. McKay, J. Phillimore and N. Teasdale (2011), 'Exploring gender and social entrepreneurship: women's leadership, employment and participation in the Third Sector and social enterprises', Voluntary Sector Review, 2 (1), 57-76.

Tracey, P. and O. Jarvis (2006), 'An enterprising failure: why a promising social franchise collapsed', Stanford Social Innovation Review, 5 (Spring), 55-70.

Tracey, P., N. Phillips and O. Jarvis (2011), 'Bridging institutional entrepreneurship and the creation of new organizational forms: a multilevel model', Organization Science, 22 (1), 60-80.

Waddock, S. A. and J. E. Post (1991), 'Social entrepreneurs and catalytic change', Public Administration Review, 51 (5), 393-401.

Williams, D. A. and K. A. K. K'nife (2012), 'The dark side of social entrepreneurship', International Journal of Entrepreneurship, 16, 63-75.

Wry, T. and J. G. York (2015), 'An identity-based approach to social enterprise', Academy of Management Review, 42 (3), 437-6o.

Yunus, M. (2011), 'Social business - towards a better capitalism', in P. U. Petit (ed.), Creating a New Civilization through Social Entrepreneurship, Piscataway, NJ: First Transaction Publishers/Goi Peace Foundation, pp. ix-xvi.

Zahra, S. A., E. Gedajlovic, D. O. Neubaum and J. M. Shulman (2009), 'A typology of social entrepreneurs: motives, search processes and ethical challenges', Journal of Business Venturing, 24 (5), 519-32. 